\title{
Johnnie the Muskrat
}

\author{
By Mrs. F. Bilsbury, Grenfell
}

Well boys and girls, I promised to tell you more about Peter, our rabbit. I can only say he still stays about the farm. He now comes to the house garden where we put a dish of chop and a few handfuls of fresh green hay.

One night I opened the door and as the moon was most brilliant I saw Peter feeding at his dish of chop. He does not make any attempt to run away. You can well understand, though, our great surprise last week, on opening the door, to see, not only Peter, but six other large rabbits enjoying the chop. Since that night they seem to be coming back.

Now I have an entirely new pet to tell you all about. This one is a pet muskrat whose name is Johnnie. When we got her, both her eyes were closed and remained so for nearly two weeks. She was terribly thin and hungry and had been badly bitten. Iler fur was very noor. We gave her an apple box in which was an old wooll en cloth; this we put behind the kitchen stool. Here was her house.

Did any of you ever try to tame a muskrat? They are about the easiest wild thing to tame and soom learnmany things. Johnnie has a very keen nose and loves oat-meal porridge. She is always ready at breakfast table for her share.

Now children, I am going to tell a secret. My little girl does not like even a tiny bit of porridge, so she slips hers to Johnnie under the table. Of course we pretend we don't know a thing.

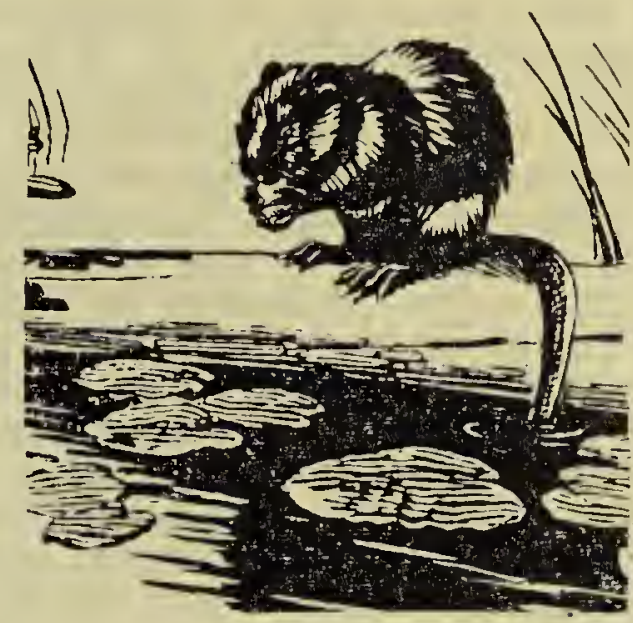

Johnnie dearly loves a piece of bread dough. She will sit up and beg until she gets it. Her main food is chop, which she steals from the pig's pail. Carrots she stores in her house along with a weird collection of bread, pieces of potato, hard candies, and cheese.

Evening is her time to go to work. She has a macaroni box full of very smooth peeled sticks. She gets the corner of the box in her strong teeth; drags it to the door and at once goes to work. Unloading the sticks, she fits them along the door to hold out the draft. She had an old comic book from which she tore all the leaves -these too, for stopping the draft. By morning she has a great pile of sticks and paper along with her box in front of the door.

When spring comes we will say goodbye to Johnnie.

Next time I write the BLUE JAY I will tell you the story of our other pet. In the meantime see if you can guess what it is.

\section{BLACKIE}

Blackie, who lives at Bladworth, was a sick dog about Christmas time, and all because he was foolish enough to grapple with a porcupine.

$\mathrm{He}$ and his master, Laurence Beckie, were standing on a bank of snow in some brush, when after sniffing the air, the dog took off through the deep snow in search of "Porky " He was called back but paid no attention. Once he hesitated and than he charged. It was too late then to do anything. His mouth and one side of his body were full of quills.

After the torture of extraction was over, and he began to feel himself once more Blackie made a New Year's resolution. In future he would give "Porkie" a wide berth. 